\title{
O DISCURSO TERAPÊUTICO E A CONSTRUÇÃO DA IDENTIDADE: UMA ANÁLISE DE DISCURSO CRÍTICA (ADC)
}

\author{
Marilene Tavares Cortez
}

\begin{abstract}
This paper examines approaches to therapeutic discourse from the point of view of Critical Discourse Analysis as it is conceived by Norman Fairclough. The main aim is to analyse how discourse practices affect the constitution of identities in late modernity. Two analytic models of therapeutic discourse will be critically revisited: the first one developed by Labov \& Fanshel (1977) within the framework of Discourse Analysis, and the second developed by Ribeiro et alii (2002) within the framework of Interactional Sociolinguistics.
\end{abstract}

Key words: Critical discourse analysis, identity, language, hegemony, identity function, psychology.

Este texto analisa alguns aspectos da relação da linguagem e da constituição da identidade no evento discursivo psicoterápico à luz da ADC, especificamente a teoria e metodologia estabelecidas por Norman Fairclough. Tal relação será investigada a partir da reanálise dos modelos discursivos terapêuticos propostos por Labov \& Fanshel (1977) e Ribeiro et alii (2002), através do referencial teórico-metodológico da ADC.

Para empreender a reanálise dos modelos discursivos, supra citados, ancoro-me principalmente nos construtos teóricos de discurso (Chouliaraki \& Fairclough, 1999: 37-52), hegemonia, função identidade e ethos, à frente definidos. Partindo da teoria faircloughiana, tomo o evento discursivo psicoterápico como uma prática social. Essa forma de conceituar e analisar a prática psicoterápica permite estabelecer uma articulação crítica para os conceitos acima referidos, discurso, hegemonia, função identidade e ethos para abordar a forma como a linguagem, compreendida também enquanto uma prática social, participa da constituição da identidade do indivíduo. 
O construto de prática social demanda, numa análise de discurso crítica, que se investigue o atravessamento das relações de poder e hegemonia nas práticas discursivas. Assim, postular o discurso terapêutico enquanto uma das práticas discursivas da modernidade tardia abre espaço para se investigar como as relações de poder e hegemonia afetarão a constituição da identidade na prática psicoterápica, uma vez que a própria prática discursiva é constituída a partir de relações de poder e hegemonia (cf. Fairclough, 1992: 60, 167-168). Como as práticas discursivas variam temporalmente, isto é, cada momento histórico tem uma forma própria de produzir o discurso, refletir sobre a constituição histórico-social da produção discursiva psicoterápica é condição sine qua non para implementar uma análise crítica dessa prática social. Contudo, uma investigação mais aprofundada sobre tal construção histórica escapa ao escopo desse trabalho. Assim, delinearei apenas alguns pontos acerca da construção histórica da prática social e discursiva do evento psicoterápico.

Antes de passar às reanálises dos modelos discursivos propostos por Labov \& Fanshel (op. cit.) e Ribeiro et alii (op. cit.), gostaria de destacar três aspectos que elucidam a forma como emprego algumas propostas teórico-metodológicas de Fairclough para empreender as reanálises discursivas.

O primeiro aspecto refere-se ao fato de Fairclough (1992: 44-45, 137, 167-168) alojar no centro de sua investigação teórico-metodológica os efeitos da prática discursiva sobre a constituição da identidade. Fairclough (ibidem) estabelece, também, o quanto a função identidade, que permite investigar como o sujeito constrói a sua identidade a partir da análise discursiva, tem sido negligenciada pela teoria da análise do discurso ${ }^{1}$. Explorar esse interesse é precisamente o objetivo deste artigo, ou seja, investigar os efeitos da prática discursiva sobre a construção da identidade do indivíduo na prática social

\footnotetext{
${ }^{1}$ Vale notar que, passados mais de dez anos desde essa afirmação de Fairclough, tem aumentado o número de estudos sobre a relação da prática discursiva e construção da identidade (cf. Hall, 2002; Burke et alii, 2000; Woodward, 2002; Sarup, 1993). Contudo, invariavelmente tais estudos tomam o referencial teórico psicanalítico para estabelecer o que é identidade, o que gera muitos outros problemas, uma vez que a teoria psicanalítica tem um forte componente hegemônico (cf. Mannoni, 1974: 79-83; Reich, 1974: 38; Fairclough, 1992: 59).
} 
psicoterápica, conforme foi dito anteriormente. Desta forma, procuro analisar como as relações sociais, manifestas nas postulações teóricas a partir das quais a prática social psicoterápica é conduzida, afetam a constituição da identidade. Dito de outra forma, "como os sujeitos sociais são moldados pelas práticas discursivas" (Fairclough, 1992: 60).

O segundo aspecto refere-se à dificuldade de empreender uma análise com tal teor, conforme destaca Fairclough (1992: 23-25). Indo além, neste mesmo texto, Fairclough (1992: 167-168) declara que um trabalho mais detalhado e técnico acerca desta relação, entre linguagem e identidade, "ainda está por ser feito". Diante dessa dificuldade, ou procurando superar tal dificuldade, apropriei-me da teoria faircloughiana buscando um espaço transdisciplinar para refletir sobre a forma como a prática discursiva atua na construção da identidade na prática social psicoterápica.

Podemos encontrar em Chouliaraki \& Fairclough (1999: 2, 16-17, 154) a defesa da necessidade de ocupar um espaço transdisciplinar para superar as limitações teórico-metodológicas da disciplina, fazendo avançar, simultaneamente, a análise crítica do discurso. Esse seria, portanto, o terceiro aspecto que caracteriza a forma pela qual tomo o referencial teórico da ADC: a busca da transdisciplinaridade para reanalisar os modelos discursivos propostos por Labov \& Fanshel (1977) e Ribeiro et alii (2002). Desta maneira procuro superar alguns aspectos teóricos que constituem entraves para a ampliação da análise discursiva, através do efeito tunelamento, comentado adiante. A transdisciplinaridade aumenta o poder de operacionalização dos construtos de uma teoria, quando tais construtos são postos a funcionar dentro da lógica de uma outra disciplina (cf. Chouliaraki \& Fairclough, 999: 16-17). Partindo de tais referências é necessário, para a consecução do objetivo deste texto, discutir o conceito de transdisciplinaridade, pois através dele procuro explorar alguns conceitos da ADC para analisar o discurso psicoterápico e mesmo a psicoterapia enquanto prática social, na intenção de superar algumas limitações da psicologia, como por exemplo, a sua forma de abordar a linguagem. Dito de uma outra forma, procuro pôr alguns conceitos da ADC para funcionar dentro da lógica da psicologia.

Outro construto que destaco é o de hegemonia, uma vez que tal conceito é axial numa reflexão crítica sobre a prática discursiva e, portanto, para as reanálises e conclusões propostas neste trabalho. Assim, este con- 
ceito irá merecer uma investigação um pouco mais longa do que os demais conceitos aqui utilizados. Passo, então, a comentar os conceitos de transdisciplinaridade e hegemonia.

\section{O Conceito de Transdisciplinaridade}

Um ponto importante é saber que o conceito de transdisciplinar se diferencia dos construtos de inter- e multidisciplinar (cf. Domingues et alii, 2001: 9-14; Weil, 1993: 30-37), tendo sido empregado pela primeira vez por Piaget em 1970, de forma a associar evento e construto teórico (cf. Weil, op. cit.: 30, 39). Piaget propõe também uma primeira definição para o fazer transdisciplinar "que não se contentaria em atingir as interações ou reciprocidades entre pesquisas especializadas, mas situaria essas ligações no interior de um sistema total sem fronteiras estáveis entre as disciplinas" (cf. Weil, ibidem). Domingues et alii (op. cit.: 18) destacam que o "prefixo 'trans', além de sua acepção de 'através' ou de 'passar por', encerra os sentidos de 'passar além', 'passagem', 'transição', 'mudança', 'transformação', aquelas de situações de conhecimento que conduzem à transmutação ou ao traspassamento das disciplinas, à escuta de suas aproximações e freqüentações ... a transdisciplinaridade permite pensar o cruzamento de especialidades, o trabalho nas interfaces ...".

A transdisciplinaridade se propõe a desenvolver também uma metodologia alternativa, segundo Morin (2001). Uma das principais referências da metodologia que se busca trabalhar na transdisciplinaridade é a aceitação de que o saber é lacunar, pois só assim há a possibilidade de se acoplar o novo numa articulação e rearticulação contínua dos saberes. Contudo, Domingues (2001: 49) irá alertar que "o transdisciplinar é ainda um conceito vazio e que deverá ser preenchido ao longo das pesquisas".

A transdisciplinaridade envolve, ainda, uma mudança na perspectiva antropológica do fazer científico. Mudança extremamente difícil, uma vez que envolve não somente os entraves teórico-metodológicos do fazer transdisciplinar que procura hibridizar conhecimentos e linguagens, mas, principalmente, porque estamos lidando com o fato de que "é toda uma práxis cognitiva que se vê de repente desestabilizada, além de profundamente alterada" (Domingues et alii, 2001: 23). 
A análise crítica aqui buscada só se tornou possível a partir da reflexão propiciada por um espaço transdisciplinar. Contudo, sabemos o quanto é espinhoso trabalhar no terreno da transdisciplinaridade, onde, eventualmente, criam-se defasagens comprometedoras entre as teorias postas a dialogar, como a que ocorre, ainda, no texto de Fairclough que mantém a perspectiva gramsciana e estruturalista althusseriana do construto de hegemonia e da relação entre poder e discurso, conforme procuro discutir em seguida. De qualquer maneira, a perspectiva transdisciplinar busca o efeito de tunelamento da física quântica (cf. Barreto, 2001: 29-30), que é o da partícula transpor barreiras de comunicação existentes entre sistemas diferentes, ou seja, a metodologia transdisciplinar procura uma forma de transpor as limitações das disciplinas de forma que elas avancem em um movimento espiralado. Assim, espero que este trabalho, que almeja construir um espaço transdisciplinar para pesquisar a relação entre linguagem e constituição da identidade na prática social terapêutica a partir das proposições da ADC, possa ser lido, não como uma conclusão, mas antes como uma abertura para novos caminhos para uma investigação tão premente como esta para a sociedade da modernidade tardia (cf. Giddens, 2002). Especialmente se nos lembrarmos que o próprio Freud, em 1933, formulou a pergunta: que visão de mundo a psicanálise constrói? Anos mais tarde, Foucault, por exemplo, irá responder tal pergunta denunciando a prática psicanalítica como uma forma de controle que a modernidade desenvolveu para disciplinar o indivíduo. Fairclough (1992: 59) parece ser um pouco mais condescendente do que Foucault e dirá que a prática psicoterápica é, no mínimo, ambivalente. Contudo, mais à frente desse mesmo texto, à página 221, Fairclough reforça sua crítica ao "aconselhamento", dizendo que tal prática envolve uma tecnologização ${ }^{2}$ do discurso e isso traz séri-

\footnotetext{
${ }^{2}$ Fairclough (1997: 92-93), discutindo os efeitos da tecnologização do discurso na prática médica, especificamente a "técnica da conversação", estabelece: “a reformulação de técnicas discursivas implica uma simulação considerável... a simulação de significados e de formas, respeitante à constituição discursiva de relações e identidades sociais... Estas novas identidades são inspiradas em modelos do "mundo da vida", da esfera privada ... a construção da identidade social pode ter conseqüências patológicas imprevistas: a simulação generalizada da conversação e dos seus valores culturais pode conduzir a uma crise de sinceridade, de credibilidade, e a um cinismo global, impossibilitando as pessoas de distinguir o genuíno do artificial".
} 
as conseqüências para a construção da identidade. Procurando centrar essa discussão em torno do objetivo deste texto, lembramos apenas que todos os aspectos citados acima, incluindo a pergunta proposta por Freud, envolvem a construção do pensamento hegemônico; assim, passo a discutir tal conceito. Antes disso, gostaria, ainda, de apontar que a remissão à psicanálise justificase em função de os atendimentos dos pacientes que têm os seus discursos analisados adotaram a psicanálise como modelo de atendimento psicoterápico.

\section{O Conceito de Hegemonia}

A definição e o manejo do construto de hegemonia são fundamentais para que as reanálises empreendidas neste trabalho promovam uma reflexão sobre as formas como as relações de poder, que permeiam todas as práticas discursivas, atuam, também, na construção da identidade na prática social psicoterápica. Buscando uma nova forma para abordar o construto de hegemonia - e a associação que se faz com o conceito de estrutura recorro a Laclau \& Mouffe (1985). Passo, então, a comentar alguns pontos dessa obra, que sustentarão algumas conclusões propostas a partir das reanálises acerca da relação linguagem, sociedade e indivíduo na modernidade tardia.

Laclau \& Mouffe (1985) introduzirão o conceito de hegemonia em seu texto a partir de uma perspectiva histórica. Rastrear as mudanças sofridas pelo conceito de hegemonia em sua trajetória teórica permite que Laclau \& Mouffe (ibidem) declarem que o que estão propondo para abordar este conceito na sociedade "pós-marxista" vai muito além do texto de Gramsci (op.cit.: 1-5). Na verdade, estes autores estão interessados em perscrutar a "lógica social implícita no conceito de hegemonia", e esta investigação sobre a dinâmica social afasta-os da formulação que Gramsci propõe para o construto de hegemonia (ibidem: 3, 136-138), conforme veremos adiante. Laclau e Mouffe procuram uma saída para os impasses teóricos promovidos pelo viés gramsciano do construto de hegemonia, uma vez que o tempo histórico hodierno é muito diferente daquele sobre o qual Gramsci se debruçou para fazer as suas reflexões teóricas sobre os eventos sociais. 
Para destacar a estreita ligação entre o momento histórico e as mudanças sofridas pelo conceito de hegemonia, é de capital importância a cronologia que Laclau e Mouffe (op. cit.) estabeleceram para analisar as modificações desse conceito ao longo da história.

O conceito de hegemonia nasceu em um contexto teórico e histórico definido (cf. Laclau e Mouffe, 1985: 7-14), sendo Rosa de Luxemburgo a primeira pensadora a se dedicar mais exclusivamente a ele (ibidem). O surgimento do conceito de hegemonia está ligado aos movimentos sociais, ou às lutas operárias russas e germânicas no início do século XX. O texto de Lênin, segundo autor destacado por Laclau e Mouffe (op. cit.: 7), a trabalhar o conceito de hegemonia, introduz novos matizes para este construto ao acompanhar, na verdade participar, dos desdobramentos das lutas proletárias russas. Resumidamente, a hegemonia é entendida, por Lênin, como um "cálculo político estratégico" na luta de classe. Gramsci, por sua vez, propõe uma nova expansão para este conceito, transcendendo a noção de "tática ou estratégia política" oriundas nas lutas de classes, noção presente em Rosa de Luxemburgo e em Lênin, sugerindo que a hegemonia exista "concretamente nas formações sociais" (ibidem).

Analisar esta localização histórica do conceito de hegemonia, como o fazem Laclau e Mouffe (op. cit.), acompanhando as modificações teóricas que este conceito vai sofrendo a partir das mudanças ocorridas nos eventos sociais, os quais o conceito de hegemonia procura cobrir, permite que estes autores prescindam do construto de estrutura social (apud Chouliaraki \& Fairclough, 1999: 120, Laclau \& Mouffe, 1985: 139-145) para refletirem sobre as relações de poder, discurso e hegemonia na sociedade da modernidade tardia ou "pós-marxista", como preferem os autores. Como foi dito, o que norteia Laclau \& Mouffe (op. cit.) na discussão que fazem em torno do conceito de hegemonia é compreender a lógica social implícita na sociedade atual. É nesta medida que vêem o construto teórico de estrutura social como originário do “... imaginário Jacobino que postulava a sociedade como uma estrutura inteligível...” (ibidem: 2); concepção que, segundo Laclau \& Mouffe (ibidem: 3) continua presente no "marxismo clássico”. Esta concepção está também presente na abordagem estruturalista althusseriana adotada por Fairclough. Seguindo o texto de Lefebvre et alii

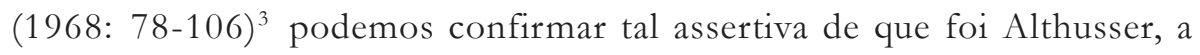


partir de uma leitura estruturalista do texto de Marx, quem acoplou os conceitos hegemonia e estrutura.

Assim, para desatrelar o conceito de hegemonia de uma topografia social, com uma localização determinável (cf. Laclau \& Mouffe, 1985: 134148), em outras palavras, para escapar à noção de estrutura, Laclau \& Mouffe (ibidem: 135) irão pensar a hegemonia como uma ininterrupta articulação e rearticulação de práticas sociais e discursivas. Assim, ao associarem os conceitos de poder, hegemonia e discurso, eles irão postular que "o poder nunca é fundacional", isto é, ele não cria uma "estrutura a partir da qual o poder é irradiado” (cf. Laclau \& Mouffe, 1985: 141). Ao contrário o poder é sempre constituído de forma pragmática na sociedade, através de interações discursivas e não discursivas, e sendo assim, a hegemonia, para Laclau \& Mouffe (op. cit: 139), é vista simplesmente como "uma forma de relação", que pode estar ligada a uma relação de poder. Ou ainda, Laclau \& Mouffe (1985: 135) irão propor que a hegemonia é um "momento articulatório", isto é, para estes autores este construto envolve, principalmente, a noção de "contingência e fronteira", procurando destacar, através destas noções, o aspecto de mobilidade e fluidez da hegemonia e não o de estrutura, que remete a estabilidades e cristalizações.

Laclau \& Mouffe (ibidem: 136-137) afastam-se definitivamente de uma construção teórica gramsciana e assumem que a hegemonia “... implica um fenômeno de fronteira... sendo impossível resumir a formação social como um referente empírico sob as formas inteligíveis de uma sociedade" (grifo meu). As constantes articulações e rearticulações das práticas sociais, movidas por contingências conjunturais, levam sempre à configuração de fronteiras e não de estruturas. Assim, seguindo Laclau e Mouffe, não é possível sustentar que a hegemonia exista concretamente em uma es-

${ }^{3}$ Lefebvre assim se manifesta sobre a leitura que Louis Althusser faz da obra de Marx: "L. Althusser reflete sobre Marx e a teoria marxista em função de um conceito de estrutura e de forma sobre cuja origem ele nada explica... sua versão (de Althusser) resulta de conceitos e de ideologias e de problemáticas elaboradas alhures, que ele introduz na leitura de Marx... Erro metodológico tanto mais grave quanto se apresenta sob o signo do rigor, com a linguagem do rigor" (op. cit.: 80). Podemos encontrar em Pedro (1997: 36-37) uma remissão a alguns autores, como Pennycook e Worsley, que "classificam de neomarxista" a perspectiva de Fairclough. 
trutura ou formação social, como fazem Gramsci, Fairclough e Chouliaraki (cf. Chouliaraki \& Fairclough, 1999: 119).

A perspectiva de Chouliaraki \& Fairclough (op. cit.) sobre a relação do poder, discurso e hegemonia advinda da teoria político-social de Gramsci e Althusser, conduz a teoria da ADC para um terreno movediço, isto é, transporta para a ADC uma série de questionamentos e rejeições feitas ao estruturalismo, especialmente em relação ao marxismo-estruturalista althusseriano, há trinta anos atrás (cf. Dosse, 1993, 1994; Lefebvre et alii, 1968). Procurando escapar à essa restrição da noção de estrutura e hegemonia, gostaria, neste momento, de estabelecer que adoto as proposições de Laclau \& Mouffe (1985), acima discutidas, no que concerne à compreensão entre o conceito de hegemonia, e sua relação com a noção de estrutura. Ou seja, entendo que a hegemonia emerge na prática social e discursiva, dito de outra forma, o pensamento, ou os valores hegemônicos, é atualizado ou construído a cada prática discursiva, não havendo, portanto, uma estrutura que encerre a hegemonia. Adotar as proposições de Laclau \& Mouffe (1985) propicia ao analista do discurso maior alcance para as suas análises, uma vez que não há um saber "naturalizado" (cf. Fairclough, 1992: 85-96) isto é, pré-existente. Como defendo, ao lado de Laclau \& Mouffe (op. cit.) esse saber hegemônico é continuamente construído a cada prática discursiva. Ou seja, tal saber é também praticado, não se aloja em nenhuma cognição, estrutura social ou discursiva anteriores, pré-existentes, conforme busco demonstrar nas reanálises a partir da ADC. Tal procedimento metodológico segue o que é proposto por Chouliaraki \& Fairclough (1999: 16-17) como um procedimento transdisciplinar de aumentar a operacionalidade teórica, ao colocar o construto de uma teoria a funcionar a partir da lógica de uma outra teoria. Bem como procuro escapar a certas construções teóricas reducionistas sobre o conceito de ideologia e hegemonia que chegam a impedir uma análise de discurso crítica (cf. Fairclough, 1992: 60).

A despeito destas limitações teóricas da ADC, em relação aos conceitos de hegemonia e estrutura, ela proporciona uma nova forma de abordar o evento discursivo terapêutico. Um dos pontos importantes que emerge a partir deste novo olhar e que remete a esta discussão da interpenetração entre os construtos das teorias que abordam a linguagem e aquelas que 
investigam o social, possibilita-me destacar alguns aspectos do evento psicoterápico enquanto contexto social, isto é, uma prática social circunscrita a uma ordem societária que apresenta uma prática discursiva específica. Como defende a ADC, a ordem societária, a partir de sua localização histórica, condiciona uma forma específica para a articulação da linguagem e da identidade. Ancorando-me nesse referencial da interface entre linguagem, prática social e indivíduo, passo a examinar o modelo de análise do discurso psicoterápico proposto por Labov \& Fanshel (1977).

\section{O MODELO DE ANÁLISE DO DISCURSO TERAPÊUTICO PROPOSTO POR LABOV} FANSHEL

Para se empreender a reanálise do discurso terapêutico analisado por Labov \& Fanshel (1977), é necessário descrever rapidamente a aplicação da "análise abrangente do discurso". Método desenvolvido por Labov \& Fanshel (op. cit.) a partir da análise de um trecho de quinze minutos do discurso de Rhoda, uma adolescente judia anoréxica, atendida por uma terapeuta no "Instituto Nacional de Saúde Mental" (National Institute of Mental Health).

Labov e Fanshel trabalham em uma perspectiva interdisciplinar para constituírem o seu método, desta forma os autores lançam mão de diferentes construtos oriundos dos diversos campos teóricos que pesquisam o evento discursivo, tais como Análise da Conversação (AC), Sociolingüística Interacional (SI), Análise do Discurso (AD) e Pragmática (P) para estabelecer uma estratégia para se analisar o discurso, a "análise abrangente do discurso". Assim, autores como Goffman e os conceitos de "face" e "interação conversacional", Austin e "atos de fala" e o conceito de "pistas paralingüísticas" são centrais para Labov \& Fanshel (1977) desenvolverem a sua análise discursiva. Para efeito deste trabalho, destaco apenas alguns conceitos empregados por Labov \& Fanshel (op. cit.), especialmente os construtos de interação conversacional, a partir dos quais fica implícita "a natureza dialógica da comunicação humana e o intenso trabalho social e lingüístico para a co-construção do significado" (Ribeiro \& Garcez, 1998: 8) e pistas paralingüísticas, tais como, entonação e prosódia. 
Será dada maior ênfase aos conceitos de entonação e prosódia por terem estes elementos lingüísticos não-verbais assumido um aspecto fundamental, sendo mesmo coluna de sustentação, para a análise discursiva empreendida por Labov \& Fanshel (1977), conforme postulam os autores:

os padrões de entonação se revelaram cruciais à medida que nosso trabalho avançava, para a definição de estilos discursivos, para identificação de padrões de conversação, para a identificação de contradições que seriam insolúveis se nós considerássemos apenas as palavras. Assim, mudanças no timbre e volume assumiram um papel de tal monta em nosso trabalho, que nós utilizamos técnicas da "fonética acústica" para tornar mais precisa a medição desses fenômenos (Labov \& Fanshel, 1977: 5-6)

Por outro lado, as pistas paralingüísticas, especialmente a prosódia, também tornaram-se um elemento crucial para a reanálise do discurso de Rhoda à luz da ADC, conforme será mostrado adiante.

Ao lado da ênfase dada à entonação enquanto elemento lingüístico não-verbal decisivo para a resolução de contradições surgidas no evento discursivo, Labov \& Fanshel (1977: 26-27) dão outra contribuição significativa para a $\mathrm{AD}$ ao mostrarem que "é o social que organiza a seqüência da conversação", ao empreenderem uma crítica ao trabalho de Sacks et alii (1975). Este apontamento que Labov \& Fanshel (op. cit.) fazem para a articulação entre o discurso e o social é grandemente ampliado, melhor fundamentado, a partir do emprego do referencial teórico-metodológico da ADC, principalmente através dos conceitos de "discurso" e "ethos", conforme veremos.

Antes de iniciar a reanálise do modelo discursivo proposto por Labov \& Fanshel (op. cit.), destaco dois excertos do discurso psicoterápico de Rhoda, que envolvem a relação dela com a sua mãe, bem como a interação da garota com a sua terapeuta.

O primeiro excerto refere-se ao relato de Rhoda sobre o afastamento prolongado de sua mãe, da casa e família, e as conseqüências criadas a partir desse fato:

Rhoda: So I says t'her, "Are you coming home tomorrow morning?" So she said, "Why - why?" 
A - and-I said - uh - "Well, it's getting a little too much.

So she said, See, I told you so." 4

(Labov e Fanshel, 1977: 164)

O destaque dado por Labov \& Fanshel (op. cit: 180) a esse trecho da entrevista analisado é que Rhoda repete esse relato por três vezes, o que é visto pelos autores como uma dificuldade da garota de desafiar a mãe, pedindo que essa volte para casa. Ao lado disso, este estilo discursivo, repetir os relatos, é também característico do estilo discursivo da família de Rhoda. Labov e Fanshel relatam, ainda, que somente na terceira vez em que Rhoda (re)conta esse episódio é que ela é capaz de introduzir a elocução da mãe "Viu, eu lhe disse" (See, I told you so), acrescentando, também, a entonação usada pela mãe para expressar tal elocução. O emprego da "análise abrangente do discurso" permite que Labov \& Fanshel (1977) postulem que é a reprodução da entonação empregada pela mãe, que permite a Rhoda começar a compreender como a sua mãe a considera, "uma pessoa incapaz de cuidar de si", uma vez que o uso da entonação tem um destaque especial na família de Rhoda, para expressar, implicitamente, o que as pessoas querem dizer (cf. Labov \& Fanshel, 1977: 164). Esse será o estigma da mãe de Rhoda em relação à filha e está ligado ao desenvolvimento da anorexia por Rhoda. Este fato é de grande relevância no contexto discursivo de Rhoda e para a constituição de sua identidade, como busco mostrar através da reanálise da fala de Rhoda.

Outro componente discursivo analisado por Labov e Fanshel diz respeito ao uso das proposições ${ }^{5}$ diretas e indiretas e que aponta para a forma como Rhoda e sua mãe se relacionam. Assim, por exemplo, a resposta da mãe a Rhoda "Viu, eu lhe disse" (See, I told you so), é uma proposição indireta, pois através dela a mãe de Rhoda corrobora a sua crença de que Rhoda não é capaz de cuidar de si. O uso das proposições indiretas, entre Rhoda e sua mãe e entre os membros da família de Rhoda,

\footnotetext{
${ }^{4}$ Mantenho o original em inglês, uma vez que as elocuções de Rhoda guardam ou expressam elementos relevantes da linguagem da garota. Os elementos lingüísticos e paralingüísticos que compõem o estilo discursivo de Rhoda teriam de ser recriados na tradução para o português, envolvendo deslocamentos inevitáveis.

${ }^{5}$ Proposição é a comunicação recorrente (cf. Labov \& Fanshel, 1977: 51).
} 
transporta uma alta carga afetiva. A frase da mãe de Rhoda, "Viu eu lhe disse", é vetor para uma grande carga de hostilidade da mãe em relação à filha, conforme destacam Labov e Fanshel ao longo de todo o capítulo 4 (cf. Labov Fanshel, 1977: 271).

Este pequeno trecho analisado possibilita acompanharmos a assertiva de Labov e Fanshel de que não são as elocuções ou a seqüência das mesmas, conforme defende a análise da conversação, que possibilita a co-construção do discurso, e sim as ações ou interações e a entonação, que são os grandes sinalizadores do que realmente está sendo dito. Somandose a isso a questão levantada pelos autores acerca das proposições indiretas, a reanálise discursiva a partir da ACD permitirá expandir a correlação entre incapacidade de cuidar de si, indo além do grupo familiar e apontando para a origem judia da família de Rhoda.

Antes de dar início a reanálise, destaco, ainda, o segundo excerto:

1.1[a] Rhoda: I don't .. know, whether ... I-I think I did - the right thing, jistalittle ... situation came up ....an' I tried to uhm .....well, try to ......... use what I - what I've learned here, see if it worked.

2.2 [b] Therapist: Well, what's your question?

(Labov \& Fanshel, 1977: 33)

Esse trecho da entrevista psicoterápica envolve a ambigüidade de Rhoda em relação à proposição da terapeuta de que "as pessoas precisam expressar as suas necessidades e emoções para outras pessoas importantes que lhes são próximas" (cf. Labov \& Fanshel, ibidem: 54). Ambigüidade que se manifesta discursivamente através da dúvida de Rhoda em não saber se fez a coisa certa, isto é, telefonar para a mãe pedindo que essa volte para casa. Através de sua ambigüidade Rhoda também desafia a terapeuta. A terapeuta reage com irritação ante tal desafio à sua autoridade e pergunta à garota: "Bem, qual a sua questão?" (Well, what's your question?). Labov \& Fanshel (1977: 113-153), através da "análise abrangente do discurso", uma análise longa e cuidadosa, irão explorar basicamente os elementos discursivos que envolvem o aspecto da ambigüidade de Rhoda, supra citado, não analisando criticamente a reação da terapeuta, a despeito de comentar, também demoradamente, tal reação. O emprego da teoria e metodologia da ADC abre muitas outras possibilidades de análise, es- 
pecialmente por vincular a prática discursiva ao contexto sócio-histórico no qual tal prática é produzida.

\section{A reanÁlise empreendida pela adC do modelo discursivo de labov \& FANSHEL (1977)}

O emprego da teoria e metodologia da ADC para a reanálise da fala de Rhoda não só amplia tal análise, mas, principalmente, introduz uma perspectiva crítica na reanálise, ao ressaltar os aspectos hegemônicos que constituem o discurso. É nesta medida que emprego os conceitos de "função identidade", que permite demonstrar como o sujeito constrói a sua identidade discursivamente (Chouliaraki \& Fairclough, 1999: 36-52), o que possibilita a investigação da interpenetração dos aspectos semióticos e sociais nas práticas discursivas, ou dito de outra forma, como a lógica social é interiorizado semioticamente pelo discurso (cf. Chouliaraki \& Fairclough, 1999: 59-51) e o conceito "ethos", que explora a noção da intertextualidade e comportamentos não-verbais enquanto elementos constitutivos do discurso e, portanto, da identidade.

Como os conceitos de discurso e intertextualidade são cruciais para a reanálise dos modelos psicoterápicos, conforme dito anteriormente, faço um breve comentário sobre tais conceitos.

O conceito de discurso proposto por Fairclough (1992) explora a interface entre o social e a linguagem, desenvolvendo, assim, uma teoria social do discurso. Isso possibilita pensar a linguagem como uma ação social e historicamente localizada. Há vários desdobramentos para essa proposição de Fairclough, destaco apenas a relação de constituinte/constituído estabelecida para a linguagem e para a social (cf. Fairclough, 2001: 32-33). Essa relação permite que se entenda a linguagem sendo constituída pelo social, bem como vê a linguagem sendo constituinte do social.

O conceito de intertextualidade permite explorar os aspectos de historicidade e hegemonia presentes na construção discursiva. Assim, conforme veremos adiante, a fala de Rhoda é reanalisada à luz da intertextualidade, ou seja, é possível cotejar a fala de Rhoda com parte da história do povo judeu, do qual ela descende. Nessa reanálise 
é possível apontar, também, para alguns aspectos do pensamento hegemônico que constituem a sua fala e o sintoma.

O referencial teórico da ADC permite que se tome a prosódia judaica de Rhoda e de sua família como exercendo a "função identidade" para Rhoda, ao adotarmos a definição de discurso como a expressão de elementos semióticos sociais. No caso de Rhoda, sempre que a garota relata algo com um conteúdo emocional ela emprega tal prosódia. Vale destacar que Labov \& Fanshel (1977: 41,115), estabeleceram que a prosódia judaica de Rhoda não é elemento relevante para a análise do discurso da garota. A partir da ADC, contudo, pode-se postular a prosódia judaica como um elemento semiótico social internalizado na prática discursiva de extrema relevância para a reanálise, pois permite, inclusive, fazer um paralelo entre o discurso e o indivíduo. Ou seja, possibilita que se pense sobre a importância que a cultura judaica tem para a constituição da identidade de Rhoda. Desta forma, torna-se possível investigar como o pensamento hegemônico presente na esfera social é rearticulado discursivamente pela mãe de Rhoda e pela própria Rhoda. Como defendemos no momento da definição do conceito de hegemonia, o pensamento hegemônico é articulado conjunturalmente continuamente, desta maneira a prosódia judaica exerce a função identidade para Rhoda, sendo rearticulado pelo discurso da mãe em relação à filha.

Como é sabido, o povo judeu sofreu uma pesada crítica devido à sua "incapacidade de cuidar de si" no pós-guerra (cf. Arendt, 1999) ${ }^{6}$, a mãe de Rhoda repete tal crítica em relação à filha. Podemos, assim, ver nesse imbricamento discursivo da esfera pública e privada, a manifestação do aspecto da "intertextualidade" que envolve o conceito de "ethos" proposto por Fairclough (1992: 167-168). Conforme defende Fairclough

\footnotetext{
${ }^{6}$ Arendt (1999) faz um estudo profundo sobre a banalidade do mal e denuncia ou relata como os próprios judeus se tornaram seus algozes "O fato bem conhecido de que o trabalho direto dos centros de extermínio ficava usualmente nas mãos de comandos judeus... como eles trabalhavam nas câmaras de gás e nos crematórios, como eles arrancavam os dentes de ouro e cortavam os cabelos dos mortos..." (op. cit: 139). Vemos uma semelhança entre o comportamento de Rhoda e dos judeus dos campos nazistas, ambos exerceram o ódio do "adversário" em si próprios.
} 
(ibidem) há sempre a busca de uma referência histórica para que a identidade seja construída, e tal construção se faz através da intertextualidade. Ainda segundo Fairclough, nesse mesmo texto, o conceito de "ethos" envolve também a análise de aspectos corporais que norteiam a construção da identidade.

O emprego e manejo do conceito de "ethos" na reanálise da fala de Rhoda expandem de forma esclarecedora a forma como os aspectos semióticos sociais emergem na linguagem - verbal e não verbal - do indivíduo que constrói a sua identidade na interface entre a esfera privada e pública. Assim, a anorexia desenvolvida por Rhoda pode ser vista, a partir do conceito de "ethos", como um aspecto da linguagem não-verbal e que pode ser associada ao holocausto sofrido pelos judeus na segunda guerra mundial. Como relatam Labov \& Fanshel (op. cit.: 9), a anoréxica apresenta a aparência de uma prisioneira de campo de concentração nazista. O conceito "ethos" nos permite perceber uma intertextualidade entre a história e cultura judaica e a prática discursiva de Rhoda, e assim, a anorexia pode ser vista enquanto elemento semiótico social que participa da constituição da identidade de Rhoda.

A partir da definição de discurso proposta por Chouliaraki \& Fairclough (1999), podemos postular, também, que Rhoda articula conjunturalmente este elemento semiótico social da anorexia, em seu discurso, fazendo com ele uma identificação, ela que pertence a uma família judia. Desta forma, este elemento discursivo semiótico nãoverbal, a anorexia, vindo do social é tomado aqui como um elemento fundamental para a reanálise da fala de Rhoda pelo viés da ADC, pois exerce a função identidade, também. Assim, na reanálise do discurso terapêutico, podemos apontar para esta interiorização dos aspectos sociais na semiótica do discurso (cf. Chouliaraki \& Fairclough, 1999: 49-50) e assim analisar a influência do social sobre a constituição da identidade. A teoria psicanalítica vê o fenômeno da anorexia ligado à díade mãe-filha (cf. Ajuriaguerra \& Marcelli, 1991: 303), já a perspectiva teórico-metodológica da ADC permite que se amplie tal análise, mostrando, através da análise do discurso, como ela pode ser vista enquanto um elemento semiótico social expresso 
discursivamente, confirmando algumas afirmações de Giddens (2002: 99-103) sobre esse fenômeno. Isto é, pensar a construção da identidade na modernidade tardia ${ }^{7}$, demanda, cada vez mais, estratégias de análise que recuperem o imbricamento dos elementos sociais na esfera privada, como propõem, também, Chouliaraki \& Fairclough (1999: 38-41).

Ao fazer estes paralelos entre o discurso e o individual, ou a esfera pública e privada $^{8}$, procuro estabelecer também, que o que efetivamente empodera o discurso são os laços afetivos que este estabelece com e entre os indivíduos. A proposição indireta da mãe de Rhoda "Viu, eu não lhe disse", tornou-se hegemônica para Rhoda e passou a desempenhar o papel de "função identidade" para a garota, transportando uma carga emocional alta, conforme vimos. Nesta medida, podemos procurar responder a questão de Fairclough (1995: 36) sobre “o que sustenta a ideologia?”, como podendo ser a carga afetiva que fica atrelada ao discurso hegemônico, é esta associação entre afeto e uma certa forma de compreender a si próprio(a) e o mundo que garante que um poder ou uma forma de pensamento se instaure como hegemônico. $\mathrm{Na}$ verdade este pensamento hegemônico é articulado e rearticulado conjunturalmente a cada interação discursiva, conforme vimos e que volto a ressaltar ao explorar a interação entre Rhoda e a terapeuta.

Para investigar a articulação e rearticulação do pensamento hegemônico e a construção da identidade faremos um breve cotejo entre as práticas discursivas da terapeuta e da mãe de Rhoda. Nesta medida, é

\footnotetext{
${ }^{7}$ São inúmeros os estudos acerca da modernidade tardia, autores como Giddens (2002) e Harvey (2002), por exemplo, estudaram esse tema. Partindo do texto de Fairclough (cf. Chouliaraki \& Fairclough, 1999), destaco apenas três aspectos presentes nesse período histórico: a ruptura da noção tempo-espaço, as mudanças fundamentais sofridas na comunicação e a fragmentação do "eu".

${ }^{8}$ Fairclough reporta-se ao texto de Habermas, principalmente, para desenvolver uma discussão acerca da relação entre a esfera pública e privada. Por ora estabelecemos apenas que a esfera privada pode ser entendida como o "mundo da vida" (lifeworld), termo oriundo da fenomenologia de Husserl e que remete à idéia de um "mundo para todos, o mundo em que vivemos intuitivamente" (cf. Cortez, 2003; Avritzer, 1996; Habermas, 1990).
} 
importante recuperar a estrutura textual ou discursiva em que emergem as frases da mãe e da terapeuta que cumprem a "função identidade" para Rhoda, igualando-a a uma pessoa que não sabe. No relato de Rhoda que se repete três vezes, há outra frase da mãe muito importante, além da frase "Viu, eu não lhe disse", que também tem aparência de uma frase inócua", mas que é altamente significativa na interação entre mãe e filha, e exerce, também, a função identidade. A frase “Oh, por quê?” (Oh, why?), dada em resposta à pergunta de Rhoda se ela voltaria para casa "amanhã", é acompanhada de uma entonação bastante especial que lembra a Rhoda a sua incapacidade de cuidar de si (cf. Labov \& Fanshel, 1977: 4849, 162-163). Assim, ambas as frases podem ser analisadas enquanto função identidade, que rearticulam uma perspectiva hegemônica entre mãe e filha e transportam uma carga afetiva acentuada, conforme destacam Labov \& Fanshel (op. cit.).

A forma como a terapeuta interage com Rhoda diante do desafio desta em relação ao "saber" da terapeuta, transcrito no segundo excerto, reproduz o mesmo padrão hegemônico que existe entre mãe e filha. Assim, diante do desafio que Rhoda lança à terapeuta dizendo que "não sabe se fez a coisa certa", a terapeuta reage com irritação, colocando Rhoda diante de uma pergunta: "Bem, qual é a sua questão?" (Well, what's your question?').

A despeito do longo comentário de Labov e Fanshel (op. cit: 124128) acerca desta resposta "irritada" da terapeuta, explorando a ambigüidade desta elocução, os autores, por não terem a perspectiva da teoria social do discurso, não percebem que esta frase serve como função identitária para Rhoda e simultaneamente promove o que temos chamado de rearticulação hegemônica da prática identitária. Labov e Fanshel não vêem que a estratégia discursiva da mãe e da terapeuta foi a mesma: responderam uma pergunta com outra pergunta, o que sinaliza a diferença hierárquica entre elas e ao mesmo tempo lembra a Rhoda que é ela própria quem ocupa a posição inferior, daquela que não sabe.

\footnotetext{
${ }^{9}$ Ver Billig (1999). Neste texto, Billig faz uma reanálise acurada de algumas sessões de pacientes clássicos de Freud, mostrando a importância axial de frases inócuas para a constituição da identidade do indivíduo.
} 
Assim, esta pergunta casual da terapeuta, "bem, qual é a sua questão?", rearticula discursivamente a "função identidade" de Rhoda, como aquela que não tem um saber. Como dissemos, a prática identitária é continuamente exercida nas interações discursivas; há sempre uma repetição da perspectiva hegemônica, inúmeras vezes aprendida na rede familiar, não havendo, portanto, uma estrutura que suporte a ordem hegemônica; ela é articulada e rearticulada simultaneamente à prática discursiva e identitária ${ }^{10}$. É importante chamar a atenção para a relação dialética entre o local e o histórico uma vez que, as práticas discursivas são historicamente construídas. Contudo, o que procuro destacar é que essa historicidade do discurso não se encontra em uma estrutura dada a priori, ou seja, a historicidade da prática discursiva se faz, por exemplo, através da intertextualidade, que atualiza o aspecto histórico do discurso em uma prática discursiva "local". A reanálise da fala de Rhoda, orientada pelo conceito de "ethos", permitiu-nos mostrar que o sintoma de anorexia e a frase que a mãe de Rhoda, "Eu não lhe disse", podem ser entendidos como índice de intertextualidade entre a cultura judaica e Rhoda. Esses índices podem ser considerados como elementos semióticos sociais, que apontam para a forma como a garota construiu a sua identidade. Não havia uma estrutura social dada a priori que contivesse tais elementos, eles foram atualizados através da interação de Rhoda com a sua mãe.

Assim, o que procurei explorar através dos construtos da "função identidade" e "ethos" foi demonstrar que a "prática identitária" é constituída localmente, isto é, não há uma estrutura que a anteceda, ela é sempre construída discursivamente. Por isso, Rhoda tem dificuldade em mo-

\footnotetext{
${ }^{10}$ A associação da ADC a outras vertentes da psicologia ampliaria o seu potencial crítico-analítico sobre o evento discursivo, neste ponto da reanálise, por exemplo, pensar esta repetição do padrão discursivo da mãe de Rhoda e da terapeuta a partir do construto de "inconsciente coletivo" ou "arquétipos", como propõe Jung; da comunicação co-consciente e co-inconsciente, conforme propõe o psicodrama; ou da multiplicidade de mensagens emitidas simultaneamente, conforme postula Milton Erickson, possibilitaria "enxergar" ou pesquisar novos elementos semióticos que envolvem o evento discursivo.
} 
dificar o seu padrão discursivo, pois ele remete à sua própria identidade. Este seria, a meu ver, ancorada nos pressupostos da ADC, o real motivo para Rhoda ter que contar e recontar o episódio descrito acima. Em outras palavras, conseguir re-estruturar a prática discursiva, ou transformar as proposições indiretas em proposições diretas, nos termos de Labov e Fanshel, significa para Rhoda ter que re-constituir a sua prática identitária; por isso é tão difícil a "negociação" discursiva com a terapeuta, conforme assinalam Labov e Fanshel - afinal, tratava-se da reconstituição da identidade de Rhoda, podemos inferir. Ao usar o termo prática identitária pretendo reforçar o aspecto exposto acima de que a identidade é praticada discursivamente também. Não há uma estrutura discursiva, cognitiva ou social que a constranja a priori, isto é, a identidade é articulada e rearticulada conjunturalmente a cada interação discursiva.

Assim, ao empregar a metodologia da ADC, que permite destacar alguns aspectos da instância social para reanalisar a prática social psicoterápica, procuro avaliar o grau de interferência do pensamento social hegemônico no processo de construção da identidade nessa prática social. Ou seja, a ampliação da investigação sobre o fenômeno da constituição da identidade, a partir da análise discursiva proposta pela ADC, possibilitou ver que há uma condução discursiva, ou um controle hegemônico sobre o discurso para que este procure sempre manter a mesma organização, que é articulada e rearticulada conjunturalmente, localmente e assim fica garantida a manutenção de uma certa identidade do indivíduo. Desta maneira, o manejo dos construtos da "função identidade" e "ethos" permitiu demonstrar que a prática identitária é constituída localmente, bem como avaliar a rearticulação do pensamento hegemônico, por parte da terapeuta, no momento da construção da identidade na prática discursiva terapêutica aqui reanalisada.

O MODELO PROPOSTO PELA SOCIOLINGÜística INTERACIONAL (SI) PARA ANALISAR O DISCURSO TERAPÊUTICO

O segundo modelo de análise do discurso terapêutico que será reanalisado é proposto por Ribeiro et alii (2002) a partir da perspectiva 
da SI. O discurso analisado pelas autoras é o de Vicente, paciente diagnosticado como esquizofrênico, uma das variações da psicose, proferido durante a entrevista de apresentação ${ }^{11}$ no Instituto de Psiquiatria do IPUB. Vicente tentou suicídio algumas vezes, sendo uma delas dentro do hospital. Na infância Vicente era freqüentemente espancado pelo pai, a violência sofrida por Vicente era extrema a ponto de o pai lesar a perna do filho.

A análise do discurso de Vicente empreendida por Ribeiro et alii (2002) tem como objetivo principal perscrutar a construção identitária que o paciente faz de si e, simultaneamente, problematizar o "rótulo" de esquizofrênico que marca Vicente. O procedimento metodológico empregado segue as proposições da SI. Assim, as autoras exploram principalmente o conceito de "enquadre" proposto por Bateson (1998) e Goffman (1998), a partir do qual descrevem, na verdade concluem, que a identidade do paciente esquizofrênico é uma "identidade multifacetada" (cf. Ribeiro et alii, 2002: 406-408, 429). Através da microanálise da entrevista de apresentação, buscando uma perspectiva interdisciplinar entre a psiquiatria, a psicanálise e a SI e considerando a fala a "via régia" para se investigar o interior do indivíduo (ibidem: 408-410), Ribeiro et alii (op. cit.) têm a intenção de problematizar a nosografia psiquiátrica e psicanalítica sobre a esquizofrenia para repensar o "rótulo" de esquizofrenia. Nesta medida as autoras procuram evidenciar que a metodologia da microanálise da "fala", desenvolvida pela SI, promove a possibilidade do(a) paciente (re)construir a sua identidade (cf. Ribeiro et alii, 2002: 408-410).

Como o conceito de "enquadre", na perspectiva de Bateson, é axial para a análise discursiva de Ribeiro et alii (op. cit.) e será retomado no momento da reanálise do modelo da SI, recupero algumas informações sobre esse conceito e o seu estabelecimento.

\footnotetext{
${ }^{11}$ Entrevista psicoterápica que ocorre em hospital psiquiátrico, na qual há um exame público do paciente. A entrevista, ora comentada, foi conduzida por um profissional que é psicanalista e psiquiatra; outras pessoas podem apenas assisti-la, sem interferir.
} 
Gregory Bateson ${ }^{12}$, antropólogo norte-americano, grandemente interessado em abordar a ocorrência do fenômeno das metamensagens ou da metacomunicação no evento psicoterápico, desenvolveu o conceito de "enquadre" (cf. Bateson, 1998: 58, 68-69). Bateson desenvolveu uma série de argumentos ou "generalizações", como ele mesmo propõe, para fornecer uma base epistemológica para a psiquiatria abordar a esquizofrenia a partir da investigação sobre a comunicação humana ${ }^{13}$ (cf. Bateson, 1998: 58). É importante destacar que a teoria da comunicação na qual Bateson se baseou é aquela fundamentada na cibernética. Sendo predominante, portanto, o enfoque da "teoria da informação" desenvolvida pelos ciberneticistas, especialmente por Norbert Wiener e Claude Shannon (cf. Dupuy, 1996). Tendo isto em mente, podemos acompanhar o autor lançando mão dos trabalhos de Whitehead e Russel, sobre a teoria dos conjuntos e lógica ${ }^{14}$, bem como os de $\mathrm{McCulloch}$, sobre a psicologia e a lógica, e afirmando que há "um certo tipo especial e importante de enquadre psicológico - a saber, um enquadre cuja função é delimitar um tipo lógico" (cf. Bateson, 1998: 66-67), "tipo lógico", que nas proposições de Bateson, garante a compreensão do discurso ao se instruir o(a) observador(a) so-

${ }^{12}$ Bateson foi um dos mais destacados participantes das Conferências Macy, iniciadas na década de 1940, em torno das quais foi constituída a ciência cibernética (cf. Dupuy, 1996). Bateson estava interessado em investigar a natureza da comunicação humana de maneira geral. Como muitos intelectuais do pós-guerra, acreditou que a pesquisa sobre a linguagem computacional lançaria luz sobre a comunicação humana (cf. Dupuy, op. cit.). Nesta medida, para se compreender mais apropriadamente as hipóteses de Bateson sobre o evento comunicativo, temos que ter claro que o campo teórico que fundamenta as bases de sua pesquisa é o da cibernética, ou uma interlocução entre cibernética, psicologia e teoria da informação.

${ }^{13}$ Schützenberger 1997: 21-22), relata que a Dra. Frieda Fromm-Reichmann, conceituada psiquiatra alemã, sugeriu quando de sua estada em Stanford nos EUA, entre os anos de 1955-1956, a um grupo de pesquisadores de Palo Alto, ao qual Bateson pertencia, que filmasse famílias que tinham algum membro esquizofrênico. O desenvolvimento desta pesquisa, da qual participavam antropólogos e psiquiatras, originou o conceito de "duplo vínculo", cunhado por Bateson.

${ }^{14}$ Sucintamente, podemos estabelecer que: "a lógica estuda a correção dos argumentos demonstrativos" (Pinto, 2001: 15-32), ou seja, o que interessa para o estudo da lógica é o cotejo entre proposições, as premissas, para concluir sobre a validade da inferência. 
bre aquilo que ele(a) deve manter dentro do campo conversacional e o que deve ser descartado como não pertencente àquele evento discursivo. Portanto, Bateson parte de todo o aparato epistemológico da cibernética, teoria da informação e metamatemática para introduzir os conceitos de paradoxo de abstração, duplo vínculo e enquadre.

Bateson (1998: 66) propõe que um enquadre é um dispositivo metacomunicativo, fornecido pelo(a) emissor(a), que tem como função precípua fornecer ao receptor(a) instruções que o(a) auxiliem a entender as mensagens incluídas no enquadre. As metamensagens "são sinais que representam outros eventos" (ibidem: 60). Partindo destes pressupostos, Bateson irá concluir que a grande diferença entre os neuróticos e os psicóticos é exatamente a capacidade que os neuróticos têm de lidar com as metamensagens e mesmo com as metáforas, pois estas, à semelhança das metamensagens, "representam algo ausente". Assim, seguindo estas proposições, infere-se que os psicóticos não conseguem fazer uma distinção entre o literal e a metáfora, conforme defende Bateson (cf. Bateson, op. cit.: 68-69). Esse é, portanto, o principal conceito que norteia a análise de Ribeiro et alii (op. cit.) do discurso de Vicente, objetivando mostrar uma outra forma de o sujeito construir sua identidade.

Descrevo, rapidamente, alguns enquadres propostos por Ribeiro et alii (2002) que identificam "a apresentação do eu no encontro face a face" (cf. Ribeiro et alii, 2002: 407), isto é, apontam para a "identidade multifacetada" de Vicente, segundo as autoras.

O enquadre de paranóia, outra variação da psicose, é associado ao relato de violência que Vicente diz ter sofrido do pai. Diante das perguntas do psicanalista sobre os motivos que teriam levado o pai a tanta violência contra Vicente, esse produz um discurso carregado de culpa. Quanto mais o analista insiste com Vicente para apresentar um motivo para a violência do pai, o discurso de Vicente torna-se "delirante", isto é, as respostas dadas por Vicente tornam-se irreais. Fato esse que não é destacado pelas autoras, que também não se surpreendem com o fato de o analista ter desrespeitado todos os sinais ou pistas paralingüística emitidas por Vicente, como mudança da entonação, sinalizando que gostaria de encerrar o assunto (cf. Ribeiro et alii, 2002: 419).

Citamos rapidamente um trecho desse enquadre: 
A: Mas por que você acha que seu pai te batia tanto?

P: Por causa da minha falta de bom relacionamento interpessoal

$\mathrm{O}$ analista busca mais esclarecimentos:

A: E como é que era?

P: Eu não me lembro, eu não me lembro. Era muito pequeno.

A: Mas como é que era ......

P: Acho que ele me batia porque eu tinha relações incestuosas com meu irmão.

A: Por quê? Ele viu você fazendo alguma coisa?

P: (pausa) Não. E também porque eu matei o meu bisavô o Doutor Eduardo (nessa época Vicente tinha cinco anos) (Ribeiro et alii, 2002: 419)

O enquadre de melancolia é estabelecido a partir da falta de vontade de viver de Vicente que "só pensa em se matar o tempo todo". Vicente refere a si próprio na terceira pessoa.

O enquadre psicológico e psiquiátrico é assim denominado por causa da forma "técnica" de Vicente falar sobre si e do seu sofrimento. Isto é, Vicente reproduz uma explicação dada pela psicanálise para o seu sofrimento, o que ele precisa é "consertar um conflito de infância". Na tentativa de compreender o que acontece com ele, Vicente diz: “... passei um tempo polarizado, polarizado no perigo... aí agora só quero saber de morrer, morrer, morrer, porque sei lá eu tentando consertar um conflito de infância, alguma coisa assim" (Ribeiro et alii, 2002: 424). As autoras ponderam que tais explicações "técnicas" que Vicente dá sobre si e seus problemas devem ser uma apropriação feita por Vicente destes saberes aos quais está submetido nestes muitos anos de internação em hospital psiquiátrico.

A possibilidade de caracterizar o discurso de Vicente a partir do estabelecimento de todos esses enquadres, permite às autoras concluir que a "identidade do esquizofrênico é multifacetada", ou seja, a microanálise no veio da SI corrobora a nosografia da psiquiatria e psicanálise. Como foi dito, a proposta de trabalho interdisciplinar buscou possibilitar que Vicente desconstruísse este discurso e identidade feitos a partir da violência, reconstruindo-os de forma mais positiva para que Vicente pudesse viver de forma mais independente. Segundo o relato das autoras, Vicente conseguiu caminhar ou conduzir a vida nesta direção, pois já não tenta se 
matar, sequer fala em suicídio. Capacitou-se a viver sozinho, mantendo o seu tratamento no IPUB, Instituto Psiquiátrico. Ribeiro et alii (2002: 429430). As autoras finalizam a análise do discurso de Vicente, no veio da SI, descrevendo a condução da entrevista pelo psicanalista e psiquiatra como adequada.

Uma perspectiva crítica acerca do discurso de Vicente e da própria psicanálise, isto é, da atuação do psicanalista nos leva a questionar o que Ribeiro et alii (2002) relatam como dado que garante uma nova identificação para Vicente: o fato de morar sozinho e continuar se tratando no IPUB; e a abordagem terapêtica que levou a isto. Como pondera Mannoni, "Como o discurso médico do século XIX, a análise tende a apresentar-se unicamente como um discurso dominante" (Mannoni, 1974: 79). Esta idéia foi difundida na discussão acadêmica por Foucault, quando este autor discute a semelhança entre a "confissão e a terapia", sendo que a terapia, na modernidade, seria a manifestação de uma microtécnica do poder empregada no sentido de modelar as pessoas (apud Fairclough, 1992: 53).

Esses questionamentos somente emergem quando se tem um olhar crítico sobre os fenômenos sociais. Passo, então, à análise do modelo da SI e a reanálise do discurso de Vicente à luz da ADC.

\section{A REANÁLISE DO MODELO DISCURSIVO DA SI}

Fairclough (1995: 187-213) defende que, através da ADC, é possível recuperar os elementos sociais que constituem o discurso, uma vez que a intertextualidade, por exemplo, faz a mediação entre o texto ou discurso e o social (ibidem: 189). O que procuro ressaltar novamente é que o que norteia a análise textual na ADC é esse imbricamento entre texto e história. Dito de outra forma, a ADC tem como elemento metodológico crucial a exploração da relação entre micro e macroanálise. Desta forma, para iniciar a reanálise do modelo proposto pela SI para analisar o discurso de Vicente, parto de um conceito comum aos dois campos, a ADC e a SI, mas que são tratados de forma extremamente diferenciada por eles: a microanálise, ou a relação entre micro e macroanálise. 
Fairclough (1992: 85-86) defende a perspectiva de que há uma mútua dependência entre a micro e macroanálise: segundo este autor, a microanálise é capaz de fornecer evidências para a macroanálise (ibidem). Há um caráter de complementaridade entre elas, pois enquanto a microanálise pesquisa o evento local, procurando descrever sua dinâmica interna, a macroanálise se volta para os processos globais, para as dinâmicas sociais mais amplas. A articulação entre ambas é feita buscando-se compreender como o evento local interage com o global de maneira imbricada. Assim, a ADC, através de sua perspectiva sociológica do discurso, isto é, trabalhando com a perspectiva de que a linguagem e o social se co-constituem, parte da premissa de que os fenômenos locais são fortemente afetados por um contexto mais amplo, histórico-social (ibidem).

Como a ADC está interessada em indagar como estas interações locais e globais ajudam a compor o discurso, a microanálise na ótica da SI é insuficiente para a proposta de pesquisa da ADC. Para Fairclough (1989: 1-2), a microanálise empreendida pela SI restringe-se a "descrever as convenções sociais imediatas" que compõem o evento. Para que a análise ganhe um caráter crítico é imprescindível que se desenvolva uma perspectiva histórico-social sobre o evento pesquisado, pois somente este olhar alargado do fenômeno social é que permite apreender as suas contradições e a sua forma de construção. Todo evento histórico, também o discursivo, é oriundo de uma luta hegemônica; há sempre um jogo de interesses conduzindo a constituição do processo histórico. Aplicando as noções da ADC, como a da sua perspectiva e análise social do evento discursivo, procurarei mostrar como se dá a atuação da hegemonia e do poder na prática discursiva exercida no hospital psiquiátrico. Esta prática discursiva será vista por mim, como representante de uma prática social hegemônica, que mantém, ainda, a identidade do psicótico atrelada à noção de patologia. Ou seja, esta prática discursiva ao ser exercitada dentro de uma instituição, reproduz o discurso hegemônico que está presente nas instituições.

Seguindo este tipo de argumento sobre a ausência de perspectiva histórica na microanálise dos sociolingüistas e os comprometimentos teórico-sociais que isto gera, Fairclough radicaliza a sua crítica sobre esta 
vertente da AD, afirmando que a SI "ajuda a naturalizar a prática discursiva hegemônica” (cf. Fairclough, 1995: 248), já que a ausência de uma análise histórico-social, macro ou crítica não permite que se demonstre a atuação de valores sócio-culturais hegemônicos que normatizam ou regulam o evento local. É neste viés que procurarei ampliar minha reanalise sobre alguns pontos dos modelos discursivos terapêuticos propostos por Ribeiro. Contudo, gostaria de corroborar a extrema importância que a microanálise tem para a ADC; o que se discute, portanto, é a forma de empreendê-la.

Assim, por exemplo, mesmo que Ribeiro et alii (2002) estabeleçam que, para analisarem o discurso de Vicente, procuram explorar o "contexto local da situação interacional", no qual elas indagam "qual é a identidade de quem fala, para quem fala, sobre o quê, para que fins, em que tom, fazendo uso de que normas sociolingüísticas" (Ribeiro et alii, ibidem: 413), elas não investigam em uma perspectiva macro, portanto histórica, o fato de que o discurso analisado por elas é produzido dentro de uma instituição psiquiátrica por um paciente diagnosticado como psicótico. Ribeiro et alii (2002) continuam trabalhando dentro da perspectiva de uma microanálise que não articula uma visão históricosocial ao evento discursivo que analisam. Reanalisar o discurso de Vicente, a partir dos pressupostos teóricos da ADC, é ter claro que a linguagem realiza funções sociais e que na sociedade da modernidade tardia a prática discursiva, cada vez mais, exerce um controle sobre os pensamentos e as ações dos indivíduos. Nesta medida, é crucial, para o desenvolvimento de uma perspectiva crítica de uma análise, procurar identificar a proposição de Harvey de que mudanças substanciais na modernidade tardia ocorrem na linguagem (apud Chouliaraki \& Fairclough, 1999: 78). Giddens (2002) desenvolve a hipótese de que as pessoas cada vez mais, na sociedade da modernidade tardia, buscam apoio nas "teorias" para construírem a sua identidade. Nesta medida, Giddens (2002: 70-103, 135-167) destaca, em vários momentos de seu texto, o fato de que, na sociedade hodierna, a terapia e os livros de psicologia são tomados como referência pelas pessoas para a construírem a sua identidade. Procuro chamar a atenção para um aspecto apenas apontado neste artigo e que não é desenvolvido, por não ser o 
seu escopo, sobre a importância de se pensar a partir de um referencial macro, ou seja, histórico e crítico, sobre as teorias psicoterápicas, e suas práticas discursivas, que servem como referencial para as pessoas construírem a sua identidade. Como vimos, isso ocorre com Vicente, ou seja, no enquadre psicológico e psiquiátrico, ele usa termos "técnicos” para referir a si próprio, isto é, Vicente também se socorre do referencial nosográfico da psicanálise para construir a sua identidade. Por outro lado, Ribeiro et alii (2002) estabelecem todos os enquadres a partir do referencial nosográfico da psicanálise e psiquiatria, para concluírem que a "identidade do esquizofrênico é multifacetada", sem, contudo, apontarem para os aspectos hegemônicos que constroem essas teorias. Destarte, a análise do discurso no veio da SI "naturaliza" o discurso hegemônico (cf. Fairclough, 1995: 248).

Desenvolvo, assim, breves comentários sobre a construção da nosografia psiquiátrica e psicanalítica, para localizar historicamente o local no qual a prática discursiva da entrevista de apresentação ocorre, procurando, inclusive, fundamentar essa crítica de Fairclough em relação à SI. Busco auxílio nos estudos de Bercherie sobre a história e estrutura do saber psiquiátrico:

... a clínica, desde a sua origem, concebeu a loucura como uma doença ... E já que se tratava de uma doença, de um processo patológico no sentido do corpo, era preciso definir as manifestações específicas, descrever processos ... começou então a busca do caso típico, puro, que se revelou uma raridade, quando não simplesmente uma construção do observador. (Bercherie, 1989: 318) (grifo meu)

Com esta citação de Bercherie, quero destacar o fato de que a microanálise feita por Ribeiro et alii (2002) sobre o "discurso psicótico", ao não desenvolver uma análise sociológica acerca do mesmo, não investiga a concepção ideológica do conceito de psicose e mesmo do saber psiquiátrico e psicanalítico. Na verdade, esta questão é mais difícil de ser formulada, pois mesmo que Ribeiro et alii (op. cit.) façam um questionamento sobre o "rótulo excludente e marginalizador da esquizofrenia" (Ribeiro et alii, 2002: 407), as autoras continuam tratando a psicose como uma "doença", como "uma patologia bastante grave" (ibidem). Ou seja, a ausência da perspectiva 
histórica sobre o construto teórico de doença e doença mental, como esta fornecida pelo excerto de Bercherie, impede que as autoras questionem a legitimidade do pensamento psiquiátrico e psicanalítico sobre a doença mental. Isto é, a microanálise empreendida por Ribeiro et alii (2002) - que sofreu, também, um cerceamento oriundo das limitações teóricas da psicanálise -, não consegue alcançar a dimensão de que o próprio conceito de doença mental é uma construção histórica e que aceitar esta definição ou partir desta definição para fazer uma análise é de certa forma legitimar o pensamento hegemônico.

Outro aspecto não contemplado pelas autoras é a presença da relação de poder entre o psicanalista e Vicente que é tomado de forma "natural" pelas autoras. Assim, é o fato de essa relação estar baseada numa hierarquia de poder que permite ao psicanalista desrespeitar a intenção de Vicente de mudar de assunto diante da insistência do psicanalista de demandar uma resposta de Vicente para o motivo da violência praticada pelo seu pai contra ele (cf. Ribeiro et alii, 2002: 418419), como foi dito anteriormente. Assim, mesmo que as autoras apontem para o fato de que “... o psicanalista situou sua posição e estabeleceu as premissas que orientam a apresentação...” (Ribeiro et alii, 2002: 413); elas não articulam a condução da entrevista pelo psicanalista com a própria condução do processo de (re)constituição da identidade de Vicente. Uma perspectiva crítica acerca da relação terapêutica questionaria a sua construção discursiva a partir da ausência de uma reflexão, por parte da teoria e do psicanalista, sobre a existência da relação de poder nessa relação. Por exemplo, há momentos claros nos quais ocorre a condução e interferência por parte do psicanalista sobre o processo discursivo. Assim, como há uma co-construção entre linguagem e discurso, pode-se apontar para a interferência do psicanalista na constituição da identidade que deveria ser feita por Vicente, por exemplo, o analista "insistiu em algumas direções que pareciam angustiar Vicente" (ibidem: 415). Esta postura fica justificada porque o analista quer ver aparecer um “sujeito", desrespeitando duplamente Vicente, que, prefere ficar em seu mundo interior, conforme o próprio paciente relata (ibidem: 426-427), e também não está pedindo que alguém traga mais angústia para sua existência tão dolorosa. Como as autoras não constro- 
em um distanciamento teórico em relação ao saber hegemônico da psiquiatria e da psicanálise, elas tomam como adequada a postura do analista de aumentar o grau de angústia do paciente para obrigá-lo a falar de si (cf. Ribeiro et alii, op. cit.: 415). Assim, o fato de o analista insistir e não respeitar o desejo de Vicente de encerrar a conversação é visto como técnica de tratamento, para o bem do paciente, para conectá-lo ao mundo externo (op. cit.: 415, 419). Contudo, dentro de qualquer outro evento conversacional, um desrespeito tão claro à pista paralingüística dada por Vicente ao analista (Vicente muda a entonação para um tom decrescente (op. cit.: 419)), de que quer mudar o tópico causaria problema na interação conversacional. A análise empreendida pelas autoras, ao não contextualizar esse discurso, que ocorre em uma instituição psiquiátrica - local produtor e mantenedor de desigualdades -, assume com naturalidade esta forma de interação entre o psicanalista e Vicente; ao lado disto, a psicanálise trabalha com o referencial teórico de que o paciente tem que estar angustiado para poder "entrar em análise", conforme foi dito anteriormente.

Assim como a psicanálise acredita que é necessário angustiar o paciente par ele "entrar em análise", a psicanálise e o analista acreditam, também, que há algo a ser decifrado na psicose (ibidem: 409). Somente uma escuta adequada, na qual se revalorize a fala do paciente, possibilita isto (ibidem: 408). Aqui nos defrontamos novamente com uma contradição, uma vez que esta escuta adequada é conduzida por premissas pré-estabelecidas a partir do saber psicanalítico (ibidem: 413); como então conseguir escutar o que o paciente traz para a entrevista, se o seu relato é sempre filtrado pela teoria psicanalítica?

Uma resposta possível que pode começar a ajudar a responder a indagações dessa ordem é, parece-nos, realizar a exigência da ADC de manter um enfoque crítico sobre o evento analisado, buscando ultrapassar os limites estreitos dos saberes disciplinares, para a construção de uma abordagem transdisciplinar. A teoria da ADC, nesta medida, por permitir construir um espaço ampliado para se abordar a linguagem e o indivíduo, uma vez que o discurso é sempre simultaneamente constitutivo de: (i) identidades sociais, (ii) relações sociais e (iii) sistemas de conhecimento e crença; e constituído por tais itens (Fairclough, 
2001: 33). Assim, revisando a análise de Ribeiro et alii (2002) sobre a fala esquizofrênica de Vicente, a partir dos pressupostos teóricometodológicos da ADC, pudemos acompanhar as autoras dizendo "que esta patologia é bastante grave", justificando o discurso hegemônico de que há "um enigma a decifrar" ou ainda de que é preciso buscar a "desalienação do sujeito... preso no emaranhado da loucura" (cf. Ribeiro et alii, 2002: 409). Desta forma, a análise do discurso de Vicente, proposta pelas autoras, corrobora a identidade construída para Vicente pelo diagnóstico psiquiátrico, isto é, a identidade de Vicente continua definida pela doença, pela psicose. Todas estas elocuções citadas acima representam, portanto, a "função identidade" fornecida pela instituição psiquiátrica ou pelo discurso hegemônico psicanalítico e psiquiátrico para o paciente. Tais elocuções ao funcionarem como "função identidade" para Vicente, apontam para o fato de a linguagem exercer, também, a função de construir as relações sociais e a identidade do indivíduo (cf. Fairclough, 1995: 207). Destarte, Vicente se vê como "um enigma a ser decifrado", "um sujeito que precisa ser desalienado", pois como vimos no "enquadre psicológico e psiquiátrico", estipulado por Ribeiro et alii (2002: 423-425), Vicente adotou várias classificações da psicanálise para (re)constituir a sua identidade, acreditando, inclusive, que ele precisava "consertar um conflito da infância" para solucionar "o seu problema"; é assim que Vicente se autorepresenta, como um "sujeito que precisa ser "consertado"”. Esta forma de Vicente se colocar "no mundo" e perante si próprio justifica a necessidade de manutenção de seu tratamento no IPUB. Assim, o que as autoras vêem como avanço, o fato de Vicente manter o tratamento de "sua psicose", pode ser visto, a partir da discussão tecida acima, como uma forma de controle hegemônico social, exercido pela psicanálise e medicina. A partir da reanálise da fala de Vicente através da ADC, podemos entender que Vicente torna-se apenas menos marginal, mas continua vivendo à margem da sociedade.

A própria divisão dos enquadres proposta pelas autoras - enquadre paranóico, enquadre melancólico, enquadre esquizofrênico - cumpre este papel de naturalizar o discurso hegemônico acerca do paciente, ajudando a compor a "função identidade", que fixa Vicente a certas re- 
presentações que o saber psiquiátrico e psicanalítico estabeleceram sobre ele e que foram naturalizadas pela análise das autoras. Mais do que representar um certo mundo para Vicente, a forma de a psicanálise, a psiquiatria e a SI compreenderem a linguagem constrói identidades que são alienígenas para Vicente. Ou seja, provém de um saber "técnico"15 que Vicente adota para si, por não encontrar uma escuta isenta de um saber hegemônico que pretende interpretá-lo e "constrói um mundo" para Vicente.

A partir do referencial da ADC, por exemplo, é possível ver a prática discursiva de Vicente apenas como uma tentativa de construir o seu "processo de auto-identificação". A exemplo do que Fairclough propõe como reanálise para o discurso analisado por Ullah (cf. Fairclough, 1995: 205-208), sobre a construção da identidade de garotos irlandeses através da "função identidade": onde Ullah vê duas práticas discursivas e, portanto, dois significados, Fairclough (ibidem) empregando o conceito de "função identidade" na análise textual, consegue capturar nas práticas discursivas dos garotos o fenômeno da linguagem construindo as relações sociais, bem como as identidades sociais.

${ }^{15}$ Vale notar que Fairclough freqüentemente discute a prática discursiva médica, a tecnologização do discurso e a construção da identidade e os efeitos corrosivos que isso traz na formação da identidade social (cf. Fairclough, 1997). No Brasil, o trabalho de Magalhães, I. Eu e tu: A constituição do sujeito no discurso médico (2000. b) também discute a relação da prática discursiva médica e a construção da identidade. Contudo, essa investigação não é explorada da mesma forma na prática discursiva psicoterápica. Procurei explorar esse ponto, a tecnologização do discurso na prática discursiva terapêutica em outro texto (Cortez, 2003). Mas resta a pergunta de fundamental interesse: se a tecnologização do discurso médico traz sérias conseqüências para a construção da identidade social, como fica esse efeito na prática discursiva psicoterápica que lida diretamente com a construção da identidade do indivíduo? Fairclough (2001: 31-81) ao discutir a mercantilização das Universidades inglesas, pergunta sobre as conseqüências éticas de tal mercantilização. Novamente podemos transportar tal indagação para a prática psicoterápica: como essa mercantilização tem afetado a prática do "aconselhamento" de forma geral na cultura ocidental? O fato de a mídia ter-se apropriado dessa prática discursiva torna a questão ainda mais delicada, sob a perspectiva da ética, uma vez que o interesse precípuo da mídia é a mercantilização. 
Outro conceito usado por Ribeiro et alii (2002) de forma a reforçar o discurso hegemônico sobre a psicose é o de "enquadre". Como discutimos anteriormente, este conceito proposto por Bateson (1972) nasceu no bojo das discussões que se faziam em torno da cibernética, especialmente nas décadas de 1940 e 1950 (cf. Dupuy, 1996). Vale lembrar que Bateson começa a desenvolver a sua idéia sobre o construto de "enquadre" em uma pesquisa que realizou em janeiro de 1952 (cf. Bateson, 1998: 59). Assim, a premissa que funda este conceito de Bateson é que a mente tem a sua dinâmica fortemente ancorada em um processamento analítico e este processamento assemelha-se ao do cálculo computacional, analítico e lógico. É a interlocução com a metamatemática ${ }^{16}$ e a teoria dos conjuntos que permite a Bateson postular que o psicótico não consegue resolver os "paradoxos de abstração"17. Busco chamar a atenção sobre esse ponto porque ele envolve a compreensão da linguagem enquanto processamento de informações,

${ }^{16}$ A metamatemática é o campo de investigação que faz da matemática o seu objeto de estudo. O envolvimento de Bateson com a cibernética levou-o a aproximar o "processamento" da comunicação humana à noção de cálculo matemático, o que permitiu a esse autor postular a metacomunicação em termos lógico-matemáticos (cf. Watzlawick et alii, 1998: 25-43).

${ }^{17}$ É importante lembrar, neste momento, que Labov e Fanshel chegaram a uma conclusão completamente diferente desta estabelecida por Bateson, ora comentada, acerca da dificuldade do indivíduo em solucionar os paradoxos e as ambigüidades que se estabelecem no evento discursivo. Para Labov e Fanshel, esta dificuldade está ancorada na entonação: "os padrões de entonação se revelaram cruciais ...para o esclarecimento de contradições que seriam insolúveis se nós considerássemos apenas as palavras" (cf. Labov e Fanshel, 1977: 5-6). Assim, vale ressaltar que as proposições de Bateson foram fundamentadas na linguagem computacional, na cibernética; enquanto Labov, que é lingüista, e Fanshel, que desenvolveu vários trabalhos sobre o evento discursivo psicoterápico, lidaram com a linguagem humana, alcançando um entendimento bastante diferenciado do de Bateson sobre o que gera os paradoxos comunicacionais. Labov e Fanshel comentam o conceito de duplo vínculo de Bateson, através do qual esse autor relaciona os paradoxos e o psicótico, mas apenas para confirmar a posição deles de que "há mais conteúdo interacional na entonação do que no texto" (cf. Labov \& Fanshel, 1977: 4849). 
noção essa que permeia, de forma geral, o campo da psicologia ${ }^{18}$ e que se tornou hegemônica a partir da cibernética e da constituição das Ciências Cognitivas. Assim, nesse momento, gostaria apenas de apontar para o fato de que Ribeiro et alii (2002), mais uma vez, não vêem o lastro ideológico que envolve os conceitos de "enquadre", "duplo vínculo" e "paradoxo de abstração" propostos por Bateson (1998), devido à ausência de uma análise crítica sobre a teoria que as autoras encampam, para empreender a análise da fala de Vicente na vertente da SI.

Conforme ressaltei, Bateson (op. cit.), guiado pelos estudos da linguagem computacional e da cibernética, vê a dificuldade de comunicação "no" psicótico, isto é, é "este tipo de indivíduo" que apresenta uma falha em seu processamento mental que não lhe permite "decifrar uma mensagem paradoxal". Mais ainda, Bateson norteando-se pelos pressupostos da "teoria da informação" 19 , prevalente no campo das Ciências Cognitivas durante longo período, pressupõe que o psicótico pretende informar alguma coisa. Como procuro mostrar, a teoria da ADC abre outras possibilidades para se compreender a linguagem e até mesmo o fenômeno da psicose. Se entendermos com Fairclough (1995: 207) que a linguagem, a função identidade são formas que o indivíduo tem para constituir a si e o mundo, acredito, guiada por tais proposições da ADC, que o fundamental nesse ponto é apenas apontar para a existência desse processo de construção de identidade por Vicente. Não re-

${ }^{18}$ Gostaria de lembrar ainda que Lacan foi um dos assíduos freqüentadores das Conferências Macy, que deram origem à cibernética. Ele passou todo o ano de 1955 ministrando o simpósio "Psicanálise e cibernética ou da natureza da linguagem". Lacan, em 1954, irá dizer que o "mundo simbólico é o mundo das máquinas". Remetemos a tais proposições de Lacan, nesse momento, por ter a teoria desse autor influenciado não apenas a psicologia, mas vários campos do conhecimento e a cultura ocidental de maneira geral, sendo referência, inclusive, para se pensar a questão da identidade. Em relação, por exemplo, aos estudos literários ou da cultura, "isso torna-se calamitoso", conforme defende Billig (1999: 7). Entendemos, portanto, que a ADC pode ajudar a psicologia a reconstruir a sua forma de compreender a linguagem.

${ }^{19}$ Resumidamente, pode-se dizer que a nascente teoria da informação, surgida a partir dos estudos de defesa antiaérea durante a segunda guerra mundial, tem em Norbert Wiener, ao lado de Claude Shannon, um de seus principais formuladores. Essa teoria explora a noção de entrada (input) de informação e a saída (output) da mesma, depois de decodificada por um receptor. Wiener aproximou seus estudos acerca da defesa antiaérea dos "processos em ação nos movimentos voluntários de um sujeito humano" (cf. Dupuy, 1996: 46-47). 
forçamos o discurso hegemônico sobre a psicose com o conceito de "enquadre", conforme fazem Ribeiro et alii (2002). Ao contrário, enxergarmos que o processo de construção de identidade atravessa várias passagens, como propõe Leloup ${ }^{20}$, ao longo de sua obra. A ADC permite recuperar a forma como a construção identitária é feita na modernidade tardia, conforme vimos acima, através da análise empreendida por Fairclough (1995: 205-208) em relação à construção da identidade social dos garotos irlandeses.

Destarte, conforme apontei, este aspecto da construção histórica da teoria psicoterápica, bem como o entendimento que ela tem de linguagem, escapa ao fulcro desse trabalho. Contudo, acredito que a ADC tem uma enorme contribuição a dar para a psicologia, para que esse campo do saber construa uma compreensão mais crítica sobre o seu fazer. Na modernidade tardia o que se vive é o que Mannoni e outros anteciparam há muito tempo sobre a atuação hegemônica da psicanálise (cf. Mannoni, 1974: 83; Reich, ibidem: 38). Contudo, tal discussão é premente na sociedade hodierna, como dissemos anteriormente, pois como discutir a questão da identidade sem abordar o campo do saber da psicologia e da psicanálise? Acredito que a perspectiva crítica que a ADC tem sobre a prática discursiva ajudará a psicologia a compreender que a linguagem cada vez mais incorpora elementos sociais semioticamente (cf. Chouliaraki \& Fairclough, 1999: 46-51) e, assim, a reformular a sua compreensão sobre o ser humano e o Self ${ }^{1}$, e a procurar avaliar o que é uma construção sócio-histórica do indivíduo sobre si e o que realmente

${ }^{20}$ Psicólogo que trabalha na vertente transpessoal da psicologia e com a psicoterapia iniciática.

${ }^{21}$ Podemos encontrar no trabalho de Varela et alii (2001: 91-118) uma discussão esclarecedora sobre a noção de Self, eu e identidade, na qual estes autores procuram ressaltar o aspecto da transcendência que envolve o construto teórico de Self. Este termo é utilizado procurando recuperar, dentro dos estudos da psicologia, o aspecto da transcendência humana como sendo fundamental para a constituição da identidade. Jean-Yves Leloup, terapeuta que pratica a terapia iniciática e trabalha com a abordagem da psicologia transpessoal, procura desenvolver uma antropologia não dualista, isto é, que não separe mente e corpo, mas que busque a unificação entre eles através do "nous". Assim, Leloup (2001: 24-27) propõe que o Self diz respeito "à profundeza humana e à profundeza do ser cósmico. O Self não destrói o eu, mas o ilumina e transforma por dentro". 
diz respeito à sua "essência" ou mundo interior. Questionar a crença de que o ser humano tem uma essência ou não, isto é, contrapor uma forma materialista de se fazer ciência a "outra", através do que entendemos que seja linguagem, parece-nos um caminho extremamente profícuo para se pensar o ser humano ${ }^{22}$ e o uso que faz da linguagem. Na verdade, o espaço transdisciplinar da ADC nos conduziu a tais fronteiras, ele nos trouxe até aqui. Acredito que a própria ADC possa ampliar tal fronteira, pois fronteiras existem para serem ampliadas.

\section{REFERÊNCIAS BIBLIOGRÁfICAS}

Ajuriaguerra, J.; Marcelli, D. Manual de psicopatologia infantil. 2a. ed. Porto Alegre: Artes Médicas, 1991.

Arendt, H. Eichmann em Jerusalém: um relato sobre a banalidade do mal. São Paulo: Companhia das Letras, 1999.

Avritzer, L. A moralidade da democracia. Belo Horizonte: Editora UFMG, 1996.

Barreto, F. A instabilidade como condição para mudanças institucionais qualitativas. In: I. Domingues (org.). Conhecimento e transdisciplinaridade. Belo Horizonte: Editora UFMG, 2001, 29- 34.

Bateson, G. Uma teoria sobre brincadeira e fantasia. In: B. Ribeiro; P. Garcez (org.). Sociolingüística interacional - antropologia, lingüística e sociologia em análise do discurso. Porto Alegre: Age Editora, 1998. p. 57-69.

Bercherie, P. Os fundamentos da clínica: história e estrutura do saber psicanalítico. Rio de Janeiro: Jorge Zahar Editor, 1989.

Billig, M. Freudian repression: conversation creating the unconscious. United Kingdom: Cambridge University Press, 1999.

Burke, L.; Crowley, T; Girvin, A. The Routledge language and cultural theory reader. London/New York: Routledge, 2000.

22 Podemos acompanhar a discussão feita por Magro (1999: 158-195) sobre a relação do entendimento do que seja o ser humano e a linguagem. Assim, citando Williams, ela diz: "Uma definição de linguagem é sempre, implícita ou explicitamente, uma definição de seres humanos no mundo” (Magro, 1999: 168). 
Chouliaraki, L.; Fairclough, N. Discourse in late modernity: rethinking critical discourse analysis. Edinburgh: Edinburgh University Press, 1999.

Cortez, M. O discurso terapêutico e a análise de discurso crítica. Faculdade de Letras, Universidade Federal de Minas Gerais, dissertação de mestrado inédita, 2003.

Domingues, I. Um desafio intelectual. In: I. Domingues (org.). Conhecimento e transdisciplinaridade. Belo Horizonte: Editora UFMG, 2001, 45-58.

Dosse, F. História do estruturalismo: o campo do signo, 1945/1966. São Paulo: Editora Ensaio, 1993.

- História do estruturalismo: o canto do cisne, de 1967 a nossos dias. São Paulo: Editora Ensaio, 1994.

Dupuy, J-P. Nas origens das ciências cognitivas. São Paulo: Editora da Universidade Estadual Paulista, 1996.

Fairclough, N. Discourse and social change.Cambridge: Polity Press, 1992. Critical discourse analysis - the critical study of language. London and New York: Longman, 1995.

——. A Análise Crítica do Discurso e a mercantilização do discurso público: as Universidades. In: C. Magalhães (org.). Reflexões sobre a Análise Crítica do Discurso. Belo Horizonte: FALE-UFMG, 2001, 31-81. —. Discurso, mudança e hegemonia. In: E. Pedro (org.). Análise crítica do discurso: uma perspectiva sociopolítica e funcional. Lisboa: Caminho, 1997, 77-104 (Coleção Universitária).

Freud, S. Conferência XXXV: a questão de uma weltanschauung. Rio de Janeiro: Imago Editora, [s.d.]. v. XXII (1933 [1932]). (Edição standard brasileira das obras psicológicas completas de S. Freud). pp. 193-222. Habermas, J. Pensamento pós-metafísico: estudos filosóficos. Rio de Janeiro: Tempo Brasileiro, 1990.

Hall, S. A identidade cultural na pós-modernidade. $7^{\text {a }}$. ed. Rio de Janeiro: DP \& A, 2002.

Harvey, D. Condição pós-moderna. 11ª ed. São Paulo: Editora Loyola, 2002 .

Labov, W; Fanshel, D. Therapeutic discourse - psychotherapy as conversation. New York: Academic Press, 1977.

Laclau, E; Mouffe, C. Hegemony \& socialist strategy: towards a radical democratic politics. London/New York: Verso, 1985. 
Magalhães, I. Eu e Tu - a constituição do sujeito no discurso médico. Brasília: Thesaurus Editora, 2000. b.

Magalhães, C. A Análise Crítica do Discurso enquanto teoria e método de estudo. In: C. Magalhães (org.). Reflexões sobre a análise crítica do discurso. Belo Horizonte: FALE-UFMG, 2001, p. 15-30.

Magro, C. Linguajando o linguajar: da biologia à linguagem. Instituto de Estudos da Linguagem, Universidade Estadual de Campinas, tese de doutoramento inédita, 1999.

Mannoni, M. A pedagogia, ciência ou política. In: C. Escobar (org.). Psicanálise e ciência da história. Rio de Janeiro: Livraria Eldorado Tijuco Ltda, 1974, 77-88.

Pedro, E. Análise crítica do discurso: aspectos teóricos, metodológicos e analíticos. In: E. Pedro (org.). Análise crítica do discurso: uma perspectiva sociopolítica e funcional. Lisboa: Caminho, 1997, 19-46. (Coleção universitária).

Reich, W. Reich e Freud. In: C. Escobar (org.). Psicanálise e ciência da história. Rio de Janeiro: Livraria Eldorado Tijuca Ltda, 1974, 37-66. Ribeiro, B. et alii. Esquizofrênico para sempre? In: L. Lopes; L. Bastos (org.). Identidades: recortes multi e interdisciplinares. Campinas: Mercado de Letras, 2002, 405- 431.

Sarup, M. An introductory guide to post-structuralism and postmodernism. $2^{\text {a }}$ ed. New York/London/Toronto: Harvester Wheatsheaf, 1993.

Schützenberger, A. Meus antepassados 1993. - vínculos transgeracionais, segredos de família, síndrome de aniversário e prática do genossociograma. São Paulo: Paulus, 1997.

Silva, E. Os caminhos da transdisciplinaridade. In: I. Domingues (org.). Conhecimento e transdisciplinaridade. Belo Horizonte: Editora UFMG, 2001, 35-44.

Varela, F. Thompson, E. Rosch, E. A mente corpórea: ciência cognitiva e experiência humana. Lisboa: Instituto Piaget, 2001. (Coleção Epigénese e Desenvolvimento).

Watzalawick, P.; Beavin, J.; Jackson, D. Pragmática da comunicação humana: estudos dos padrões, patologias e paradoxos da interação. São Paulo: Editora Cultrix, 1998. 
Weil, P.. Axiomática transdisciplinar para um novo paradigma holístico. Weil, P.; D’Ambrosio, U.; Crema, R. In: P. Weil; U. D’Ambrosio; R. Crema. Novos rumos à transdisciplinaridade: sistemas abertos de conhecimento. São Paulo: Summus Editorial, 1993, 9-72.

Woodward, K. (ed.). Identity and difference: culture, media and identities. London/Thousand Oaks/New Delhi: Sage Publications, 2002. 